\title{
Construct Validity Testing Using Factor Analysis on Language Development Assessment Instruments of Early Childhood
}

\author{
Utsman \\ Nonformal Education Department \\ Semarang State University \\ Semarang Indonesia \\ utsman@mail.unnes.ac.id
}

\begin{abstract}
The purpose of this study was to test the construct validity using factor analysis on the assessment instrument early childhood language development. This research was conducted with models of Research and Development with twice tried. The first test performed on 80 early childhoods and the second trial conducted on 160 children younger children in Karanganyar, Central Java Indonesia. In the first attempt succeeded factor analysis extracted seven factors, which corresponds to the number of factors that are estimated in accordance with the theoretical study, and none of the items that pass the "cut off point" $<0.30$. Obtained internal consistency reliability coefficient alpha of 0.950 . Likewise, the second trial successfully extracted 7 factors in accordance with the theoretical study and none of the items that pass the "cut off point" $<0.30$ and obtained internal reliability coefficient alpha of 0.936 . It can be concluded that the instrument assessment early childhood language development is developed has good construct validity and internal consistency reliability coefficient is very high.
\end{abstract}

Keywords—validity; analysis; factors; instruments

\section{INTRODUCTION}

One of the most important activities in the research is to develop research instruments that can be trusted and be able to measure things that are supposed to be measured, including measures that are abstract variables such as intelligence, learning outcomes, motivation, attitudes, and interests [1]. The development of research instruments often arises various problems, which were related to the validity and reliability of the instrument. There are two important characteristics that must be owned by any measurement tool, namely the validity and reliability. An instrument can be said to have high validity if the device runs measuring function in accordance with the intention of doing the measurement [2]. The validity of instruments to determine whether the research actually measure what should be measured in the study [3]. Valid instrument is an instrument that can be used to measure what should be measured [4]. The instrument used to perform the measurements must first be validated before use. One way to validate by using the construct validation. With the construct validity can enrich domain in building theory, in addition to the items with the same can measure a particular construct [5].
Validation constructs by factor analysis can see the existence of the constructs in these variables.

Intended use factor analysis was basically to summarize the mutual relationship between the variables that exist precisely, as a helper in making sense of the building. Validation constructs by factor analysis can see if the specification of theoretical constructs developed in accordance with the concept underlying construct after the tests in the field.

Through factor analysis of the items that was developed to measure the achievement of early childhood language development can come together to form a group in a single construct. Thus the elements on each item related to each other and support each other, thus forming a construct called early childhood language development. Early childhood language development in kindergarten can include any of the following.

\section{"Understends some conjunction;, defines familiar nouns; asks where \& how questions; asks definitions of words; follows 3 unrelated command in paper order, points to chest, heels, ankles and, jaws; names of colors, green, yellow, orange, and purple; understands sequencing of event when told; can describe differences in object; name color brown, black, pink, white, gray; uses five word sentences; participation in conversation without monopolizing it; uses words related to sequence; uses tomorrow \& yesterday; answer the telephone; and can repeat sentences of nine and ten syllables" [6].}

Relevant research that has been done concluded that the language skills of children in kindergarten has a positive relationship with the academic and social abilities while in elementary school grades 1 and 2 [7]. Kindergarten program managed to improve the school readiness of children in language development [8]. The examined the effects of preschool education on children's language development. As a result, treatment during kindergarten influence score letter recognition, spelling scores, and scores matter applied [9].

Research which saw the relationship between age and understanding phonology. The results showed that age affects the accuracy of speech and understanding phonology. 
Conclusion, this study illustrates, the magnitude of the effect on understanding speech phonological accuracy is affected by the child's age [10].

The examines the process of phonological and reading in children. It studies the relationship between phonological processing skills before entering kindergarten and reading skills at the end of first grade of primary school. The study was conducted at the age of prataman childhood and repeated at the start of primary school. The results showed that phonological processing weakness in all groups fairly stable for more than two years [11]. Phonological children do not experience fluctuations over a period of more than two years, and this gives the sense that the development of children's language is always evolving with increasing age of the child [11].

His researched [12] understanding of phonemes in children aged 3 and 4 years old. He identifies the understanding phonology and literacy development of children aged 3-4 years, and observing the response of children to interventions in various activities with the intention of facilitating an understanding of phonemes and letter knowledge and improve the ability to speak. Results showed that (a) an understanding of phonemes can be achieved if there is speech intelligibility, and (b) improving the understanding and knowledge of letters phonemes during the preschool years was associated closely with spelling and reading exercises early age. It can be stated, that basically learning the language for the child would be better if reproduced exercise, and the exercise of language development of children will experience a significant increase.

Santrock examined the language development of young children. The results showed that the higher the age the more vocabulary. The resulting research shows, children aged 1-6 years learn 5-8 new word's meaning in every day, at the age of 6 years old children already have a vocabulary of about 8,000 to 12,000 . This indicates that children learn language faster, and the more the vocabulary of children will not decrease [13]. All of these studies did not explain how the research instruments developed and validated. Though validation testing is an essential prerequisite for an investigation.

Based on the background of the problem, the research is intended to test the construct validity using factor analysis on the assessment instrument is the achievement of early childhood language development. Achievement of early childhood language development, in this study was the achievement of language development of children aged $5-\leq 6$, which includes a variety of capabilities described by [14]; [15]; [6]; and [16]. Traffic-ability in question is able to: understand other people communicate, understand how to communicate in a simple, able to communicate the identity, can also display the position, was able to name the objects around it, capable of relating the picture story that has been demonstrated, and can recognize symbols for preparatory reading. Following that are the focus of this research: 1) Are instruments developed already have construct validity using factor analysis? 2) What is the reliability of the assessment instrument is the achievement of early childhood development are developed?

\section{RESEARCH METHODS}

This study was conducted in early childhood kindergarten in Karanganyar district, Central Java Province of Indonesia. Procedure development of instruments in this study conducted in several stages, namely: formulating constructs of theory review, develop an indicator variable, making grating instrument, set the parameters in a continuum, writing items instruments, validate theoretical, revise the validation results of theoretical validating empirical and calculating the reliability first stage, validate and count the reliability of the empirical coefficient second stage, calculate the coefficient of reliability and revise it.

The research sample to test empirically the first phase involving as many as 80 early childhoods at kindergarten age $5-6$, and the trial in the second stage involving as many as 160 samples of early childhood. In this phase, involving as many as 16 kindergarten teachers in 16 institutions kindergarten. Prior to the trial, there are several treatments that are given to teachers, namely: to train kindergarten teachers and organizing pilot activities.

Data analysis is done by: First, using factor analysis, this analysis is used to calculate the validity of the instrument of accession early childhood language development are developed investigators. The instrument is declared invalid if it does not pass the charge factor "cut off point" $<0.30$. There are four basic steps to carry out the analysis of factors, namely (1) calculate all correlation matrix for each variable, (2) extraction factor, (3) rotation, and (4) to name each factor. In the factor analysis, there are two approaches, namely (1) exploratory approach (exploratory factor analysis) through the method of principal component analysis (PCA), and a confirmatory approach (confirmatory factor analysis) through the analysis of the maximum likelihood method (ML). Exploratory approach is used to see how many factors are needed to explain the relationship between a set of indicators by observing greater load factors. Confirmatory approach was used to test whether a number of factors empirically derived in accordance with the number of factors that have been developed theoretically or test

Second, calculate reliability. How to calculate the reliability can be measured in several different ways, namely: (1) repeatedly giving tests on the same sample in a short period (reliability test-retest), (2) the method of internal consistency, usually associated with a coefficient alpha Cronbach and variants, (3) the method split (split-half method), and (4) methods form parallel (parallel-form method). In this experiment, alpha internal consistency reliability using Cronbach's Alpha analysis method, this analysis is used to calculate the coefficient of reliability of the instrument, and magnitude of Cronbach's Alpha reliability coefficient specified 0.7 .

Third, uses confirmatory factor analysis, to see whether or not fit a model. A model declared fit, if Chi-Square $\left(\chi^{2}\right)$ obtained from the test has a probability greater than $0.05(\mathrm{p}>$ 0.05), Root Mean Square Error of Approximation (RMSEA) $<0.03$. Before the calculation by confirmatory factor analysis to test for normality and multicollinearity assumptions required to meet the statistical test. The analysis method is done with the aid of a computer program. 


\section{RESUlTS AND Discussion}

The first step in the analysis of factors to calculate the validity of the first trial is to calculate the correlation matrix of the order of $80 \times 24$. The computational results obtained KMO MSA 0,800 classified either as greater than 0.5 (> 0.5). Bartlett's Test of Sphericity obtained Chi-Square value of 2398.032 on 276 degrees of freedom with statistical significance $0.000<0.5$. Thus the correlation matrix instead of correlation matrix formed so that the identity of the factor analysis is eligible to be continued.

TABLE I. VALUE KMO AND BARTLETT'S TEST LANGUAGE DEVELOPMENT ASSESSMENT INSTRUMENT (LDAI) IN THE 1ST TEST

\begin{tabular}{lll}
\hline Kaiser-Meyer-Olkin Measure of Sampling Adequacy. & .800 \\
\hline Bartlett's Test of Sphericity & Approx. Chi-Square & 22398,032 \\
& Df & 276 \\
& Sig. & .000
\end{tabular}

Observing the Anti Image Correlation on (AIC) was not found items that have a price MSA below $0.50(<0.50)$ so that the next all items LDAI continue to be included in the analysis process. Total Variance Explained computational results of the 24 items analyzed, the value of the characteristic (eigenvalue) were 7 factors. Of the seven factors KMO MSA value obtained 0,800 , this means greater than 0.50 , therefore the calculation process is continued. Characteristic value (eigenvalue) that get more than one (>1) there are seven factors, namely: 1) understand the communication, 2) can be communication in a simple, 3) can communicate identity, 4) can also display positions, 5) can mention surrounding objects, 6) capable tells the story image, and 7) recognized symbols for preparatory reading. This suggests that many factors in the achievement of children age appropriate language development indicators estimated. Thus it can be said that LDAI is valid in terms of the construct.

The percentage of variance load factors could account for the variance of the achievement of early childhood language development are: first factor loadings $22.087 \%, 16.370 \%$ second, third $13.814 \%, 11.570 \%$ fourth, fifth $9.392 \%, 7.928 \%$ sixth, and seventh $6.836 \%$. The cumulative seven factors are $87.995 \%$.

Views scree plot that is the explanation for a total variance explained in graphic form. Scree plot diagram shows how downward trend eigenvalues to determine subjectively the many factors that shape.

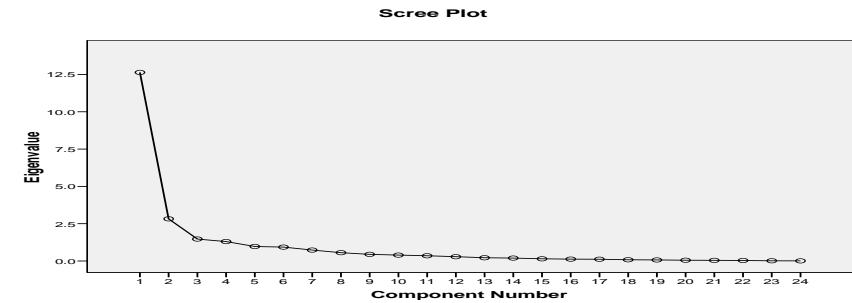

Fig. 1. Scree Plot LDAI in the 1st Test

The calculation result on Rotated Component Matrix shows there are items that pass load factor "cut off point" $<0.30$. The factor loadings contained in item number 2 and 3 amounted to 0.968 and the smallest factor loading contained in item number 1 at 0.823 . Thus all the items are valid.

TABLE II. DISTRIBUTION LOADING FACTOR OF ITEM LDAI IN THE 1ST TEST

\begin{tabular}{|c|c|c|c|c|c|c|c|}
\hline $\begin{array}{l}\text { Fact } \\
\text { or }\end{array}$ & $\begin{array}{l}\text { Names } \\
\text { factor }\end{array}$ & $\begin{array}{l}\text { Distri } \\
\text { bution } \\
\text { Items }\end{array}$ & $\begin{array}{l}\text { Loading } \\
\text { factor }\end{array}$ & $\begin{array}{l}\text { Fact } \\
\text { or }\end{array}$ & $\begin{array}{l}\text { Names } \\
\text { factor }\end{array}$ & $\begin{array}{l}\text { Distri } \\
\text { bution } \\
\text { Items }\end{array}$ & $\begin{array}{l}\text { Load } \\
\text { ing } \\
\text { facto } \\
\mathrm{r}\end{array}$ \\
\hline 1 & LF1 & $\begin{array}{l}\text { L1 } \\
\text { L2 } \\
\text { L3 } \\
\text { L4 }\end{array}$ & $\begin{array}{l}0.823 \\
0,968 \\
0,968 \\
0,916\end{array}$ & 5 & LF5 & $\begin{array}{l}\text { L16 } \\
\text { L17 } \\
\text { L18 }\end{array}$ & $\begin{array}{l}0,90 \\
5 \\
0,96 \\
2 \\
0,91 \\
7\end{array}$ \\
\hline 2 & LF2 & $\begin{array}{l}\text { L5 } \\
\text { L6 } \\
\text { L7 } \\
\text { L8 }\end{array}$ & $\begin{array}{l}0,945 \\
0,929 \\
0,926 \\
0,841\end{array}$ & 6 & LF6 & $\begin{array}{l}\text { L19 } \\
\text { L20 } \\
\text { L21 }\end{array}$ & $\begin{array}{l}0,83 \\
9 \\
0,84 \\
8 \\
0,91 \\
1\end{array}$ \\
\hline 3 & LF3 & $\begin{array}{l}\text { L9 } \\
\text { L10 } \\
\text { L11 } \\
\text { L12 }\end{array}$ & $\begin{array}{l}0,957 \\
0,950 \\
0,907 \\
0,903\end{array}$ & 7 & LF7 & $\begin{array}{l}\text { L22 } \\
\text { L23 } \\
\text { L24 }\end{array}$ & $\begin{array}{l}0,92 \\
0 \\
0,93 \\
6 \\
0,89 \\
6\end{array}$ \\
\hline 4 & LF4 & $\begin{array}{l}\text { L13 } \\
\text { L14 } \\
\text { L15 } \\
\end{array}$ & $\begin{array}{l}0,929 \\
0,892 \\
0,928 \\
\end{array}$ & & & & \\
\hline
\end{tabular}

At Rotated Component Matrix shows there are items that pass load factor "cut off point" $<0.30$. The factor loadings contained in item number 13 of 0.928 and the smallest factor loading contained in item number 11 of 0.793 . Thus all items of the statement are valid.

LDAI reliability test results showed that all items have coefitience LDAI instrument reliability Cronbach's Alpha $(\alpha)$ is greater than 0.70 , the lowest 0.953. Thus all LDAI instruments are reliable, meaning that all items instrument has high internal consistency for the computational.

\section{CONCLUSION}

The results of the factor analysis in the first test of the limited sample and the second test to the samples expanded by using exploratory methods, extraction results showed there were 7 factors. The extraction of the seven factors point 
statement obtained as many as 24 items. Ectraction of the seven factors that give a percentage of the total variance of $87.995 \%$ in the trials for the First and $84.433 \%$ for the second trial. All loading factor worth over 0.30. Computing with maximum probability confirmatory methods (ML) obtained suitability test goodness of very significant.

Results of testing the koefesiensi internal consistency reliability alpha in the first and second test instruments LDAI obtained koefesiensi reliability Cronbach's Alpha $(\alpha)$ of $>0.70$. Thus all LDAI instruments are reliable, it all means items instrument has high internal consistency for the computational results show that each item acquired over the reliability coefficient> 0.70 .

\section{ACKNOWLEDGMENT}

The author would like to thank the Ministry of Research and Higher Education to provide funding for this research.

\section{REFERENCES}

[1] Y. S, Ary, "Introduction to Research in Education," Eighth Edition. Wadsworth: United States. 2006.

[2] D. J. Mueller,"Measuring Social Attitudes," New York and London: Teacher College, Columbia University. 1986.

[3] Saifuddin, A," Reliabilitas Dan Validitas," Yogyakarta: Pustaka Pelajar. 2003.

[4] J. Coryell,. B. F. Amy and M.H. Stephen," Concurrent and construct validity of the Pediatric Evaluation of Disability Inventory," Physical Therapy. 70.10 p 60, 1990.

[5] R.D. Tojib and L.F. Sugiyanto, "Construct Validity Assessment in IS Reserach Methods and Case Example of User Satisfaction Scale," Journal of Organization and End User Computing, 23 (1) 38-39, JanuariMarch. 2011.

[6] P. A. Coughlin, "Creating child-centered classrooms: 3-5 years olds,"Washisngton, DC: Children's Resourses International, Inc. 1997.

[7] K.M. LaParo and R.C. Pianta, "Predicting children's competence in the early school years. Meta Analytic Review," Review of Educational Research, 70, 443-484, 2000.

[8] W. T. Gormley et al." The effect of universal pre-K on cognitive development,"Journal Development Psychology, 41, 872-884. 2005.

[9] K.D. McDowell., C. J. Lonigan, and H. Goldtein, "Relations among socioeconomic status, age, and predictors of phonological awarness," Journal of Speech, Language, and Hearing Research, 50, 1079-1092, 2007.

[10] S. Rvachew, "Phonological processing and reading in children with speech sound disorder," American Journal of Speech-Language, 16, 260-270, 2007.

[11] G. Gillon, "Facilitating phoneme awareness development in 3-and 4years-old children with speech impairment," Language, Speech, and Hearing Journal, 36, 308-324, 2005.

[12] J. W. Santrock, "Life-span development (5th ed.)," Auckland: McGrawHill International Book Company, 2002.

[13] H. L. Jackman,'Early education curriculum: A child's connection to the world (4th ed). Belmont, CA: Delmar Cengage Learning, 2009.

[14] S. C. Wortham, "Early childhood curriculum developmental bases for learning and teaching," New York: Macmillan College Publishing Company, 1994.

[15] J. A. Brewer, "Introduction to early chlidhdood education: Preschool through primary grades (6th ed)," Sidney: Pearson Education, Inc. 1617, 2007. 